\title{
Effective microorganisms impact on photosynthetic activity of Arabidopsis plant grown under salinity stress conditions
}

\author{
HAZEM M. KALAJI ${ }^{1}$, MAGDALENA D. CETNER ${ }^{1}$, IZABELAA. SAMBORSKA ${ }^{1}$, \\ IZABELA LUKASIK ${ }^{2}$, ABDALLAH OUKARROUM ${ }^{3}$, SZYMON RUSINOWSKI $^{4}$, \\ STEFAN PIETKIEWICZ ${ }^{1}$, MICHAŁ ŚWIĄTEK ${ }^{5}$, PIOTR DĄBROWSKI $^{6}$ \\ ${ }^{1}$ Department of Plant Physiology, Warsaw University of Life Sciences \\ ${ }^{2}$ independent researcher \\ ${ }^{3}$ Department of Chemistry and Biochemistry, University of Quebec in Montreal \\ ${ }^{4}$ Institute for Ecology of Industrial Areas \\ ${ }^{5}$ Microbiological Institute of Technology in Turku (ITM) \\ ${ }^{6}$ Department of Environmental Improvement, Warsaw University of Life Sciences - SGGW
}

\begin{abstract}
Effective microorganisms impact on photosynthetic activity of Arabidopsis plant grown under salinity stress conditions. Salinity is one of the main abiotic stressors which affects plant growth through various physiological processes such as photosynthesis. The aim of this work is to study the impact of salinity stress on Arabidopsis plants by evaluating plant growth rate and photosynthetic activity, while investigating the influence of effective microorganisms (EMs) with the objective to determine if EMs could alleviate the induced stress affiliated with salinity. Results showed that salinity negatively affects photosynthesis efficiency in Arabidopsis plants based on the data obtained from the measured chlorophyll fluorescence parameters. Additionally, application of EMs enhanced plant tolerance to counteract the induced stress. Effective microorganisms concentration of $10 \mathrm{~mL} / \mathrm{L}$ suggested to bring about the best results. This work advocates, that quantum efficiency of photosystem II (PSII) is a reliable indicator for tolerance in Arabidopsis plants to salinity stress, the impact of which may be softened by the EMs.
\end{abstract}

Key words: photosystem II, salt stress, tolerance, photosynthetic efficiency, effective microorganisms

\section{INTRODUCTION}

Salt stress is an environmental factor that limits the growth and productivity of plants (Boyer 1982, Munns 1993, 2002). The negative effect of salinity on plant growth is a result of changes in nutrient uptake and specific sodium and chloride ion effects (Kalaji and Pietkiewicz 1993, Marschner 1995, Kalaji and Rutkowska 2003). In response to salt stress, all the major processes in plant such as protein synthesis, lipid metabolism, and photosynthesis are affected (Parida and Das 2005).

Photosynthesis is considered as one of the most important metabolic processes in plants and its performance is greatly affected under stress conditions (Baker 1991, Kalaji and Łoboda 2007, Kalaji et al. 2014c]. It has been reported that salt stress enhances the photoinhibition of photosystem II - (PSII) (Kalaji et al. 2011). However, in a changing environment, plants were able to adapt 
their metabolism in order to cope with stress.

In recent years, the technique of chlorophyll fluorescence has become ubiquitous in plant ecophysiology studies. The chlorophyll fluorescence measurement is a sensitive method that allows detecting changes in general bioenergetic conditions of photosynthetic organisms (Goltsev et al. 2012, Brestic and Zivcak 2013, Kalaji et al. 2014a, Dąbrowski et al. 2015). Indeed, chlorophyll fluorescence parameters were used to identify stress conditions in plants which are very sensitive to stress impact (Baker and Rosenqvist 2004, Brestic et al. 2013, Kalaji et al. 2014b).

In recent years, some successful efforts have been made to substitute excessive application of mineral fertilizers with natural substances and so to minimize the adverse effects of contamination (Javaid 2006, Stępień et al. 2014). One of these efforts was selection of beneficial soil microorganisms. Soil microorganisms can facilitate nutrient absorption by plants, promote plant growth and stimulate seedlings (Bowen and Rovira 1966, Brown 1974). Effective microorganisms (EMs) are a mixed culture of beneficial, naturally-occurring microorganisms mostly used or found in foods (Higa and Parr 1994), and it was originally developed as an alternative for agricultural chemicals. According to Higa and Parr (1995), EMs preparations are reported to include populations of lactic acid bacteria, yeasts, and smaller numbers of phototrophic bacteria, filamentous fungi and Actinomycetes. These effective microorganisms secrete beneficial substances such as vitamins, organic acids, chelated minerals and antioxidants when in contact with organic matter. It has been reported that crops grown with EMs have less nitrate ions, decreasing the plant's pest and pathogen susceptibility, and higher vitamin $\mathrm{C}$ and carbohydrate levels. Besides developing mechanisms for stress tolerance, microorganisms can also impact some degree of tolerance to plants towards abiotic stresses (Grover et al. 2011), and a variety of mechanisms have been proposed behind microbial elicited stress tolerance in plants (see Fig. 1 in Grover et al. 2011). Numerous studies have demonstrated that the association with soil-containing microbes can increase the resistance of plants against below-ground attack, such as that caused by soil born fungi, bacterial pathogens, and nematodes, or aboveground herbivore attack and shoot pathogens (Megali et al. 2013). Hence, the objective of this study was to investigate if EMs treatment can prevent salt damages in Arabidopsis thaliana plants. The effect of salt stress on plants photosynthetic activity was analysed by using chlorophyll $a$ fluorescence technique.

\section{MATERIAL AND METHODS}

Arabidopsis thaliana plants are widely used as one of the model organisms for studying plant sciences, including genetics and plant development. In this study Arabidopsis thaliana (Columbia) seeds (3-4 per pot) were germinated in dark conditions, in plastics multi-plant pots containing soil and sand mixture $(2: 1$ $\mathrm{v} / \mathrm{v}$ ) to provide enough space in the soil for roots growth and respiration. Seedling were transferred into a Phytotron and grew at $20 / 18^{\circ} \mathrm{C}$ day/night temperatures; under eight-hour day light (ca 
$200 \mu \mathrm{mol}$ photons $/ \mathrm{m}^{2} / \mathrm{s}$ light intensity) and 16-hour night; with approximate $75 \%$ of air humidity. Seedlings were covered by plastic foil to maintain proper humidity in multi-pot soil. Three weeks later, the seedlings were transferred to spate pots (only one seedling per pot). Five days later, plants were transplanted to bigger pots and then allowed to grow for four more weeks. Plants were watered with distillate water every day keeping the soil near the field capacity. After seven weeks in total of growth, the salt treatment was initiated. Salinity treatment was achieved by watering the plants with a salty solution $7.0131 \mathrm{~g} / \mathrm{L}$ of $\mathrm{NaCl}(120 \mathrm{mmol} \mathrm{NaCl} / \mathrm{L})$. The EMs formulation used in experiments has been obtained via sugarcane molasses fermentation initiated with composition of 12 species of microorganisms (belonging to: Bacillus subtilis, Bifidobacterium animalis, B. longum, Lactobacillus acidophilus, L. casei, L. delbrueckii subsp. bulgaricus, L. fermentum, L. plantarum, Lactococcus lactis subsp. lactis, Streptococcus thermophilus, Rhodopseudomonas palustris, Saccharomyces cerevisiae). After two-week propagation microflora EMs reached stable density (7.2-7.6 $\log ^{10} \mathrm{CFU} / \mathrm{mL}$ ) and $\mathrm{pH}$ below 4.0 and was applied in plant treatment. Plants treatment was divided in three series: control plants (10 plants), salinity plants (10 plants) and salinity plants treated with EMs (10, 50 and $100 \mathrm{~mL} / \mathrm{L}$; 10 plants for each treatment).

Chlorophyll content (three replications on each plant) was measured using Minolta SPAD 502 Meter (Spectrum Technologies, Inc., USA) and chlorophyll $a$ fluorescence measurements (using FMS2 Modulated Chlorophyll Fluo- rescence System - Hansatech Instruments Ltd., UK) were done in three terms: once before stress and twice during the stress application (after one and two weeks of salt stress). FMS2 is a lightweight, field portable chlorophyll fluorimeter using the pulse-modulated principle. It is suitable for non-invasive sampling under natural light conditions and may be combined with other techniques such as infra-red gas analysis (IRGA) for simultaneous measurements. All light sources, fluorescence detectors and temperature compensated electronics are housed within the field rugged enclosure. The light sources used are: (1) $594 \mathrm{~nm}$ amber modulating beam (optional $470 \mathrm{~nm}$ blue LED); (2) dual-purpose halogen actinic/saturating pulse lamp; (3) $735 \mathrm{~nm}$ far-red LED source for preferential PSI excitation. In this study, three fluorescence parameters were selected: the maximum fluorescence signal of light-adapted plants $\left(F_{m}{ }^{\prime}\right)$; steady state fluorescence yield $\left(F_{s}\right)$; quantum efficiency of PSII (ФPSII).

Statistical analyzes were performed by using Statistica ver. 10 Software. Analysis of variance (one-way ANOVA) was used to analyze the variance associated with the treatments, Fischer's test was used as post-hoc test with level of significance $\alpha=0.05$ to determine the significance of differences between the means. The Pearson procedure with level of significance $\alpha=0.05$ was applied to calculate the correlation coefficient.

\section{RESULTS AND DISCUSSION}

The effect of salt treatment and application of EMs on the chlorophyll content, maximum fluorescence yields of light- 
-adapted samples $\left(F_{m}{ }^{\prime}\right)$ and quantum efficiency of PSII ( analysed. By two weeks of induced salt stress. Visible signs of stress were evident in the form of wilted leaves (Fig. 1).

Indeed, effect of salinity on chlorophyll content was shown in Figure 2. Chlorophyll content increased with plant development in control plants and we observed that salt stress did not affect chlorophyll content during the first week of its application. However, there was a considerable reduction in chlorophyll content (about $60 \%$ comparing with control plants) after two weeks of salinity application. Interestingly, we observed that EMs treatment $(10$ and $50 \mathrm{~mL} / \mathrm{L})$ had a positive effect on chlorophyll content (Figs 1 and 2). This parameter was significantly associated with plant growth. Two weeks after stress application values of chlorophyll content in plants treated by 10 and 50 varied in range from 30.8 to 34.4 r.u. and were similar to values meas-

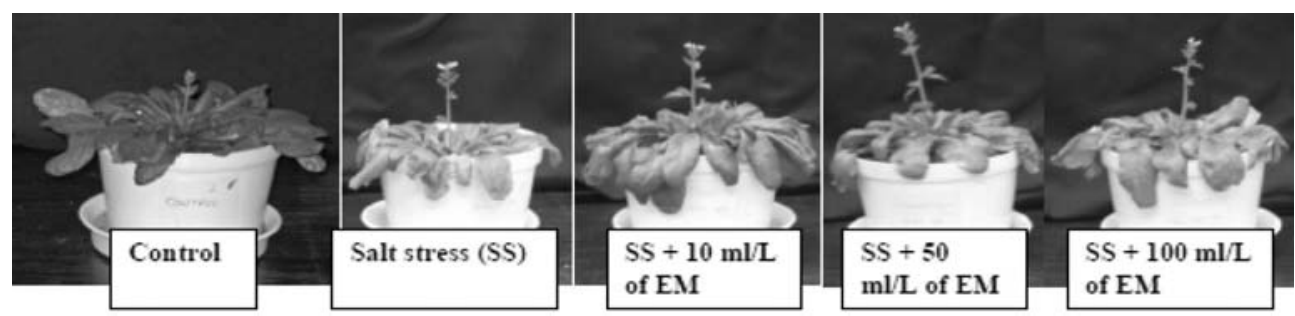

FIGURE 1. Effect of salt stress Arabidopsis plants treated or not by 10,50 and $100 \mathrm{ml} / \mathrm{L}$ of EMs

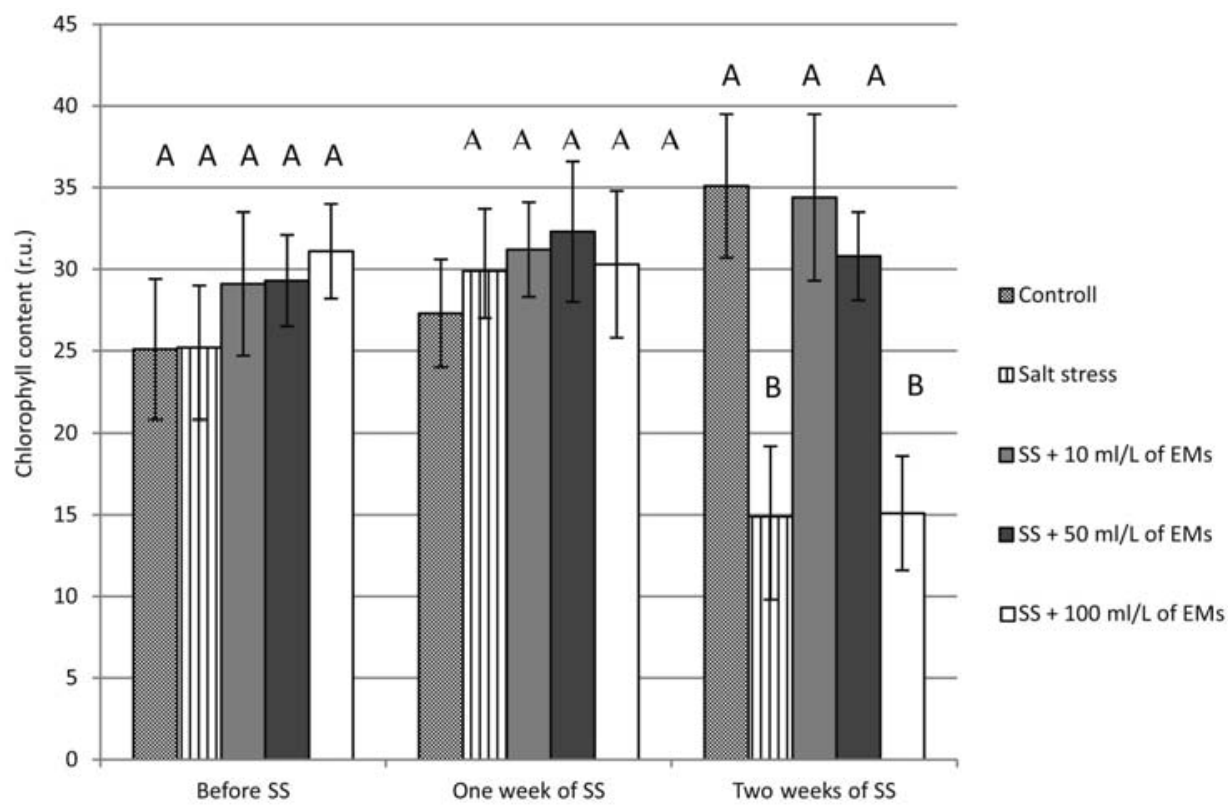

FIGURE 2. Change of chlorophyll content in Arabidopsis plants subjected to salt stress (SS) and treated or not by 10,50 and $100 \mathrm{ml} / \mathrm{L}$ of EMs. Means marked by this same letter within one term are not differ significant 
ured in control plants (35.1 r.u.), while in plants stressed were significantly lower (15 r.u.). It has been reported that changes in chlorophyll function take place before changes in chlorophyll content, and therefore alterations in the fluorescence signal occur before any visible signs are apparent (Krause and Weis 1991).

We further investigated PSII photochemistry in the light-adapted leaves. In this state, the results of the maximum fluorescence signal of light-adapted plants $\left(F_{m}{ }^{\prime}\right)$ showed similar trend to chlorophyll content (Fig. 3). The value of $F_{m}$, (related to photochemical quenching) for control plants increased with time. However, within following two weeks of salt stress $F_{m}$ ' decreased. In salt-stressed plants treated with 10,50 and $100 \mathrm{~mL} / \mathrm{L}$ of EMs, we observed that effective mi- croorganisms had a positive effect on salinity treated plants compared to plant stressed by salt without EMs. The values of steady state fluorescence yield $\left(F_{S}\right)$ before stress application ranged from 320 to 355 r.u. (Fig. 4), and the averages did not differ significant. One week after salt application there were also no significant differences between averages. Two weeks after salt application there were noted significant higher values of $F_{s}$ parameter in plant treated only by salt in compare to control plants and plants treated by salt and EMs. The results obtained by Flexas et al. (2002) and Cendrero Mateo et al. (2012) provide evidence that $F_{S}$ measurements, even without normalization, are an easy means to monitor changes in plant photosynthesis, and therefore, provide a rapid assessment of

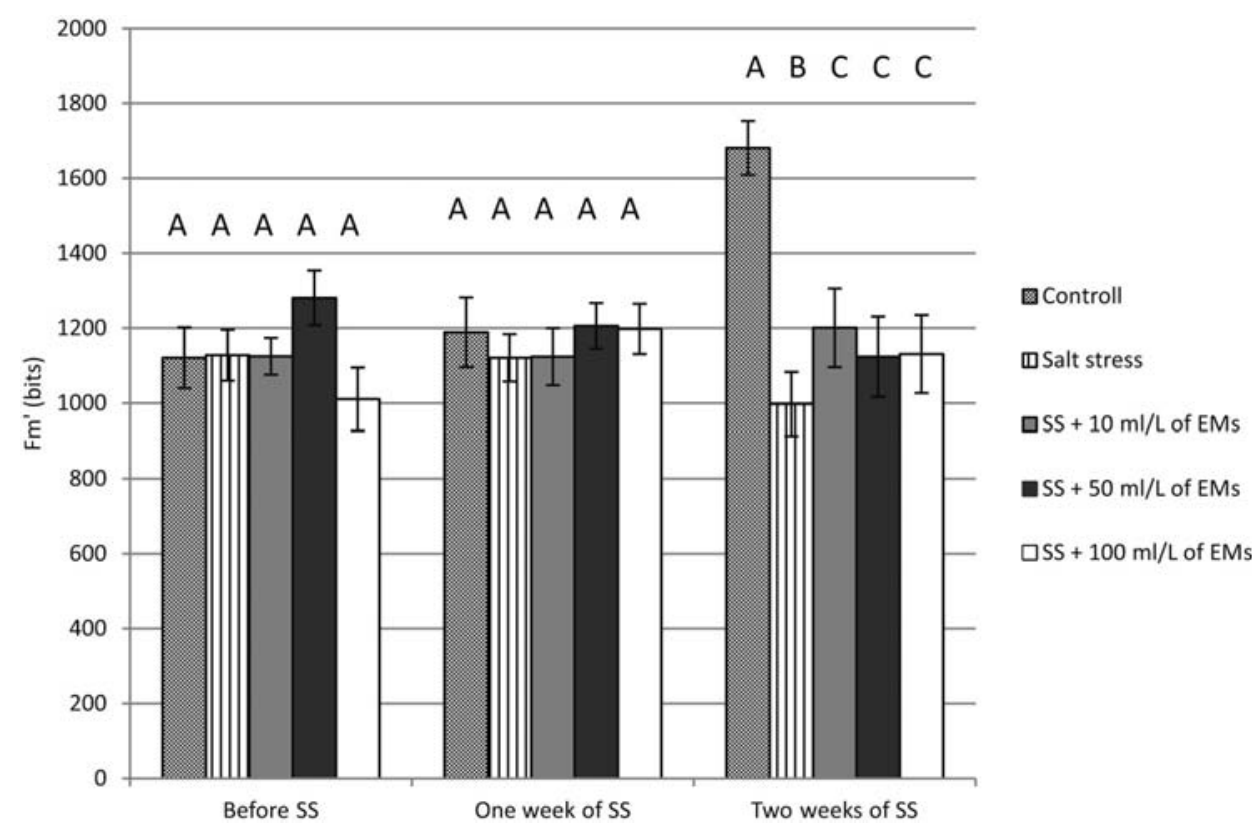

FIGURE 3. Changes in the maximum fluorescence signal of light-adapted plants $\left(F_{m}{ }^{\prime}\right)$ in Arabidopsis plants subjected to salt stress (SS) and treated or not by 10,50 and $100 \mathrm{ml} / \mathrm{L}$ of EMs. Means marked by this same letter within one term are not differ significant 


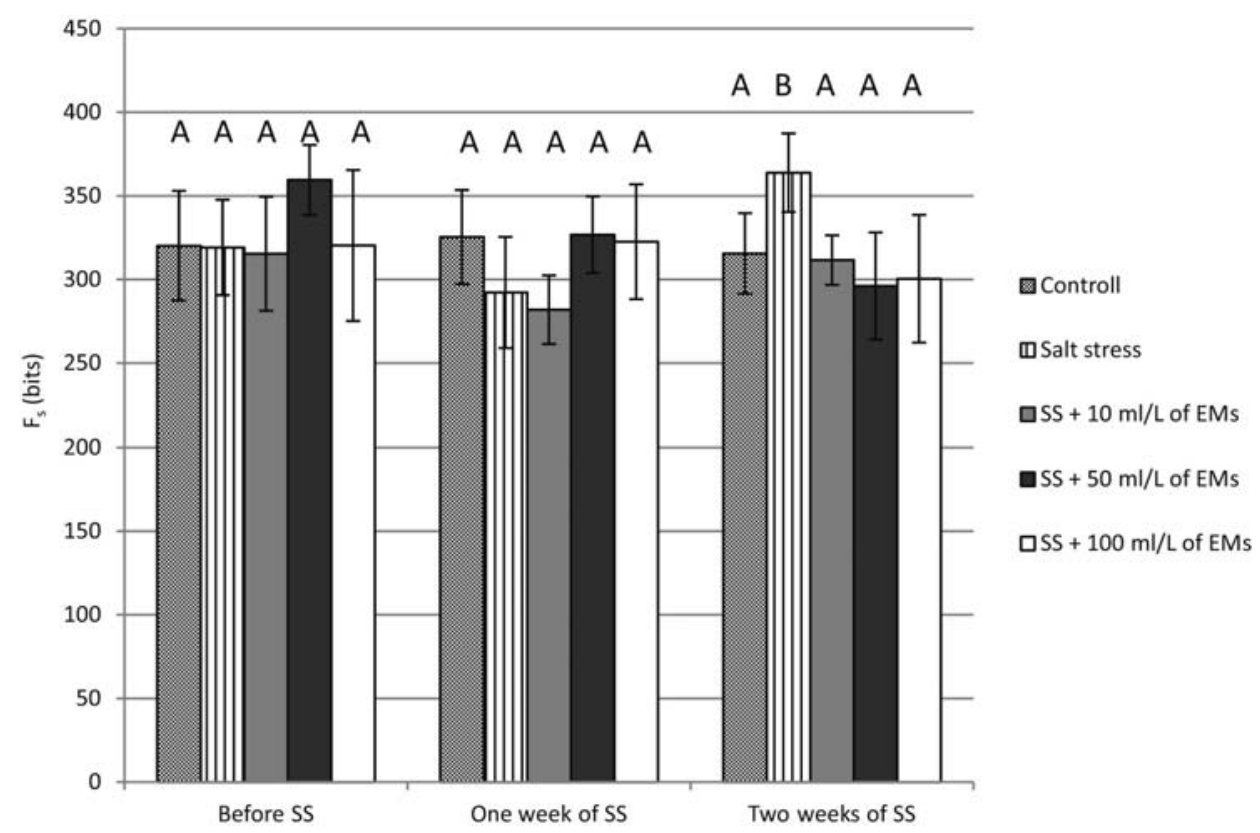

FIGURE 4. Changes of the steady state fluorescence yield $\left(F_{s}\right)$ in Arabidopsis plants subjected to salt stress (SS) and treated or not by 10,50 and $100 \mathrm{ml} / \mathrm{L}$ of EMs. Means marked by this same letter within one term do not differ significantly

plant stress to guide farmers in resource applications.

Figure 5 shows the changes in the quantum efficiency of PSII ( $\Phi P S I I)$ in control, salt stressed plants and salt-stressed plant treated with different concentration of EMs. We observed that the salt stress had a slight effect on $\Phi P S I I$ after the first week of stress application. However, we observed that after two weeks of stress, $\Phi P S I I$ decreased by $76 \%$ compared to control plants and it has been reported that salt stress enhances the photoinhibition of PSII (Kalaji et al. 2011). On the other hand, EMs treatment showed that $10 \mathrm{~mL} / \mathrm{L}$ of EMs treatment had higher positive effect on salt-stressed plants compared to treatments of 50 and $100 \mathrm{~mL} / \mathrm{L}$ of EMs. Based on statistical analysis, it should be noted, that there is significant correlation between chlorophyll content and $F_{m}$ ' parameter (Table), which was also correlated to others measured parameters.

Numerous studies have demonstrated that EMs application in soil induced range of events with beneficial affect for plants; it has been evidenced that EM moderate of water-air relations in soil (Kaczmarek et al. 2007) affect the activity of dehydogenases and phosphatases (Kaczmarek et al. 2008), initiate changes in microflora composition (Okorski and Majchrzak 2007) and finally support the humification process of organic matter (Yamada and Xu 2001, Valarini et al. 2002) which all of them could be stated as an example of indirect mechanism of plant acclimatisation supporting by microorganisms. One the 


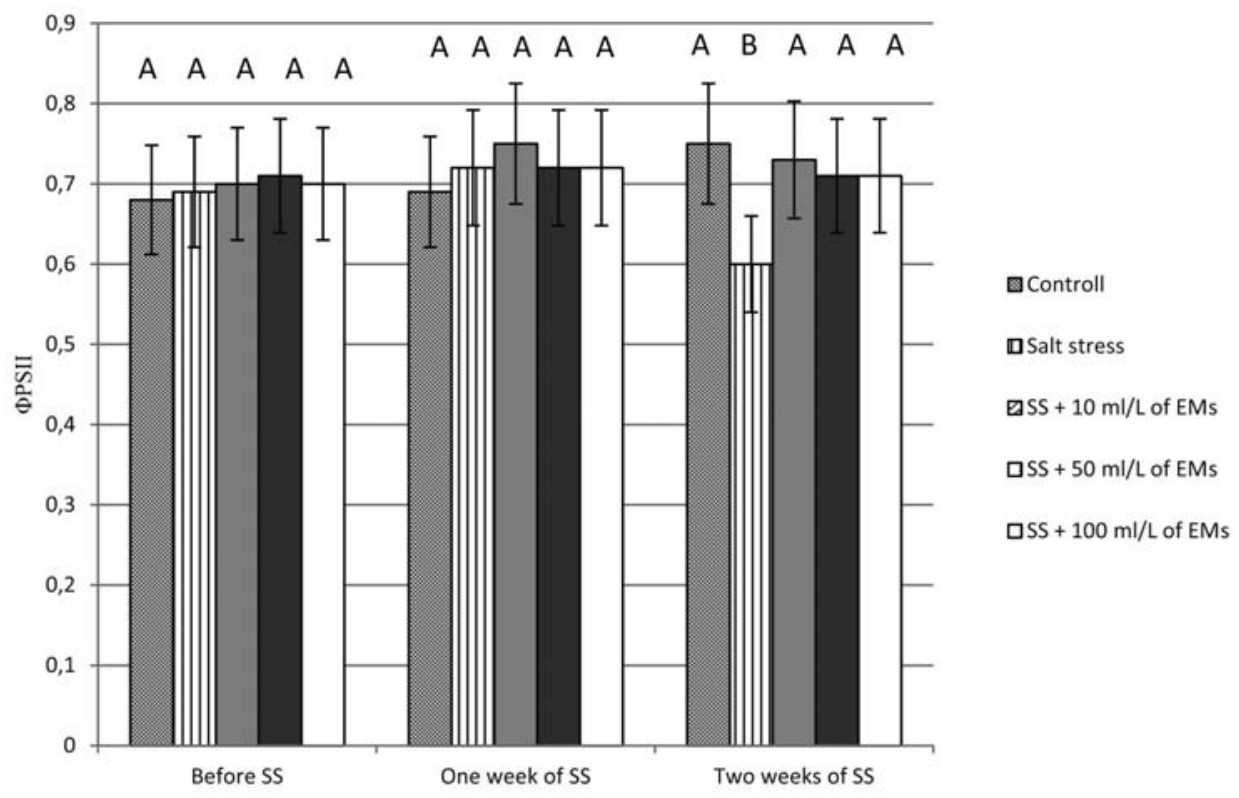

FIGURE 5. Changes of the quantum efficiency of PSII ( $\Phi P S I I)$ in Arabidopsis plants subjected to salt stress (SS) and treated or not by 10,50 and $100 \mathrm{ml} / \mathrm{L}$ of EMs. Means marked by this same letter within one term do not differ significantly

other hand EMs could affected plants directly by influencing antioxidative status of stressed plants. Talaat (2015) indicated that EMs treatment of common bean (Phaseolus vulgaris L.) cv. Nebraska to soil salinization changed the polyamine balance under saline conditions. Moreover, EMs application significantly reduced the activities of diamine oxidase and polyamine oxidase in salt-stressed plants. Both the modulation of polyamine pool and the regulation of protein synthesis can be one of the most important mechanisms used by EMs-treated plants to improve plant adaptation to saline soils (Talaat 2015). In other experiment it has been suggested that EMs-treated plants detoxified the stress generated by salinity by enhancing the $\mathrm{H}_{2} \mathrm{O}_{2}$-scavenging capacity of

TABLE. Correlation coefficient between chlorophyll content and chlorophyll $a$ fluorescence parameters

\begin{tabular}{|l|c|c|c|c|}
\hline Parameter & Chlorophyll content & $F_{s}$ & DPSII & $F_{m}{ }^{\prime}$ \\
\hline $\begin{array}{l}\text { Chlorophyll } \\
\text { content }\end{array}$ & - & 0.14 & 0.14 & $0.18^{*}$ \\
\hline$F_{S}$ & 0.14 & - & 0.08 & $0.60^{*}$ \\
\hline$\Phi P S I I$ & 0.15 & 0.08 & - & $0.75^{*}$ \\
\hline$F_{m}{ }^{*}$ & $0.18^{*}$ & $0.60^{*}$ & $0.75^{*}$ & - \\
\hline
\end{tabular}

${ }^{*}$ Significance at $p=0.05$. 
the ascorbate-glutathione cycle after inoculation with EM which significantly improved plant growth and productivity (Talaat 2014). It has been described that treatment with Bacillus ssp. strains could alleviate the effect of salinity directly thanks to restricted $\mathrm{Na}^{+}$uptake by roots (Ashraf et al. 2004). In the opinion of the authors, utility of EMs allows the possibility to further preserve environmental integrity and public health through the use of less intensive and more sustainable agricultural practices by reducing the inputs of negative effect of some environmental conditions. Our studies indicate that, there is opportunity to mitigate salt stress in plants by using EMs.

\section{CONCLUSIONS}

Effective microorganisms (EMs) seems to enhance tolerance of Arabidopsis thaliana plants from salt stress due to increasing plant chlorophyll content and quantum efficiency of PSII. The alleviation of stress in plants treated with EMs observed by stimulation of photosynthetic activity could be partly related to improved nutritional mechanisms. It is clear that low EMs concentration $(10 \mathrm{~mL} / \mathrm{L})$ has the significant effect on salt-stressed plants. These results demonstrated that EMs treatment efficiently improved plants against the detrimental effects of salt. Based on these results, application of EMs can help to minimize the effects of unfavourable environmental conditions for sustainable plant growth and optimize soil productivity without the use of chemical fertilizers and pesticides.

\section{REFERENCES}

ASHRAF M., HASNAIN S., BERGE O., MAHMOOD T. 2004: Inoculating wheat seedlings with exopolysaccharide-producing bacteria restricts sodium uptake and stimulates plant growth under salt stress. Biology and Fertility of Soils 40 (3), 157-162.

BAKER N.R. 1991: A possible role for photosystem II in environmental perturbation of photosynthesis. Physiologia Plantarum 81, 563-570.

BAKER N.R., ROSENQVIST E. 2004: Applications of chlorophyll fluorescence can improve crop production strategies: an examination of future possibilities. J. Exp. Bot. 55 (403), 1607-1621.

BOWEN G.D., ROVIRA A.D. 1966: Microbial factor in short-term uptake studies with plant roots. Nature 211, 655-666.

BOYER J.S. 1982: Plant productivity and environment. Science 218, 443-448.

BRESTIC M., ZIVCAK M., OLSOVSKA K., KALAJI M.H., SHAO H., HAKEEM K.R. 2013: Heat Signalling and Stress responses in photosynthesis. In: K. Rehman Hakeem, R. Rehman, I. Tahir (Eds). Plant signalling: Understanding the molecular cross-talk. Springer Verlag.

BRESTIC M., ZIVCAK M. 2013: PSII Fluorescence techniques for measurement of drought and high temperature stress signal in crop plants: protocols and applications. In: G.R. Rout, B.A. Das (Eds). Molecular Stress Physiology of Plants, 87-131.

CENDRERO MATEO M., CARMO-SILVA A., SALVUCCI M., MORAN S.M., HERNANDEZ M. 2012. Steady-state chlorophyll fluorescence $\left(\mathrm{F}_{\mathrm{s}}\right)$ as a tool to monitor plant heat and drought stress. American Geophysical Union, Fall Meeting 2012.

BROWN M. 1974: Seed and root bacterization. Ann. Rev. Phytopath. 12, 181-197.

DĄBROWSKI P., PAWLUŚKIEWICZ B., BACZEWSKA A.H., OGLĘCKI P., KA- 
LAJI H. 2015: Chlorophyll a fluorescence of perennial ryegrass (Lolium perenne L.) varieties under long term exposure to shade. Zemdirbyste-Agriculture 102 (3), 305-312.

FLEXAS J., ESCALONA J.M., EVAIN S., GULIAS J., MOYA I., OSMOND B.C., MEDRANO H. 2002: Steady-state chlorophyll fluorescence (Fs) measurements as a tool to follow variations of net $\mathrm{CO}_{2}$ assimilation and stomatal conductance during water-stress in $\mathrm{C}_{3}$ plants. Physiologia Plantarum 114, 231-240.

GOLTSEV V., ZAHARIEVA I., CHERNEV P., KOUZMANOVA M., KALAJI H.M., YORDANOV I., KRASTEVA V., ALEXANDROV V., STEFANOV D., ALLAKHVERDIEV S.I., STRASSER R.J. 2012: Drought-induced modifications of photosynthetic electron transport in intact leaves: Analysis and use of neural networks as a tool for a rapid non-invasive estimation. Biochimica et. Biophysica Acta 1817, 1490-1498.

GROVER M., ALI S.Z., SANDHYA V., RASUL A., VENKATESWARLU B. 2011: Role of microorganisms in adaptation of agriculture crops to abiotic stresses. World Journal of Microbiology and Biotechnology 27, 1231-1240.

HIGA T., PARR J.F. 1994: Beneficial and effective microorganisms for a sustainable agriculture and environment. INFRC (International Nature Farming Research Center), Atami.

HIGA T., PARR J. 1995: Beneficial and effective microorganisms in a sustainable agriculture and environment. Technology Trends 9, 1-5.

JAVAID A. 2006: Foliar application of effective microorganisms on pea as an alternative fertilizer. Agron. Sustain. Dev. 26, 257-262.

KACZMAREK Z., OWCZARZAK W., MRUGALSKA L., GRZELAK M. 2007: The influence of effective microorganisms for some of physical and water properties on arable-humus horizons of mineral soils. Journal of Research and
Applications in Agricultural Engineering 52 (3), 73-77.

KACZMAREK Z., WOLNA-MARUWKA A., JAKUBUS M. 2008: Changes of the number of selected microorganism groups and enzymatic activity in the soil inoculated with effective microorganisms (EM). Journal of Research and Applications in Agricultural Engineering 53 (3), 122-127.

KALAJI H.M., BOSA K., KOŚCIELNIAK J., ŻUK-GOŁASZEWSKA K. 2011: Effects of salt stress on photosystem II efficiency and $\mathrm{CO}_{2}$ assimilation of two Syrian barley landraces. Environ. Exp. Bot. 73, 64-72.

KALAJI H.M., ŁOBODA T. 2007: Photosystem II of barley seedlings under cadmium and lead stress. Plant Soil Environ. 53, 511-516.

KALAJI M.H., JAJOO A., OUKARROUM A., BRESTIC M., ZIVCAK M., SAMBORSKA I.A., CETNER M.D., ŁUKASIK I., GOLTSEV V., LADLE R.J., DĄBROWSKI P., AHMAD P. 2014a: The Use of Chlorophyll Fluorescence Kinetics Analysis to Study the Performance of Photosynthetic Machinery in Plants. In: P. Ahmad (Ed.). Emerging Technologies and Management of Crop Stress Tolerance. Vol. 2. DOI: http://dx.doi.org/10.1016/ B978-0-12-800875-1.00015-6.

KALAJI M.H., OUKARROUM A., ALEXANDROV V., KOUZMANOVA M., BRESTIC M., ZIVCAK M., SAMBORSKA I.A., CETNER M.D., ALLAKHVERDIEV S.I., GOLTSEV V. 2014b: Identification of nutrient deficiency in maize and tomato plants by in vivo chlorophyll a fluorescence measurements. Plant Physiol. Bioch. 81, 16-25.

KALAJI M.H., PIETKIEWICZ S. 1993: Salinity effects on plant growth and other physiological processes. Acta Physiol. Plant. 143, 89-124.

KALAJI M.H., RUTKOWSKA A. 2003: Short-term response of photosynthetic machinery of maize seedlings to salt 
stress. Acta Physiol. Plant. 25 (3), 80, supplement.

KALAJI M.H., SCHANSKER G., LADLE R.J., GOLTSEV V., BOSA K., ALLAKHVERDIEV S.I., BRESTIC M., BUSSOTTI F., CALATAYUD A., DĄBROWSKI P., ELSHEERY N.I., FERRONI L., GUIDI L., HOGEWONING S.W., JAJOO A., MISRA A.N., NEBAUER S.G., PANCALDI S., PENELLA C., POLI D.B., POLLASTRINI M., ROMANOWSKA-DUDA Z.B., RUTKOWSKA B., SERODI J., SURESH K., SZULC W., TAMBUSSI E., YANNICCARI M., ZIVCAK M. 2014c: Frequently Asked Questions about in vivo chlorophyll fluorescence: practical issues. Photosynth. Res. 122, 121-158.

KRAUSE G.H., WEIS E. 1991: Chlorophyll fluorescence and photosynthesis: the basics. Annu. Rev. Plant Phys. 42, 313-349.

MARSCHNER H. 1995: Mineral Nutrition of Higher Plants. Academic Press, London.

MEGALI L., GLAUSER G., RASMANN

S. 2013: Fertilization with beneficial microorganisms decreases tomato defenses against insect pests. Agron. Sustain. Dev. 34 (3), 649-656.

MUNNS R. 1993: Physiological processes limiting plant growth in saline soils: some dogmas and hypotheses. Plant, Cell Environ. 16, 15-24.

MUNNS R. 2002: Comparative physiology of salt and water stress. Plant, Cell Environ. 25, 239-250.

OKORSKI A., MAJCHRZAK B. 2007: Fungi isolated from soil before the seeding and efter harvest of pea (Pisum sativum L.) after application of bio-control product EM 1. Acta Botanica 60 (1), 113-121.

PARIDAA.K., DAS A.B. 2005: Salt tolerance and salinity effects on plants: a review. Ecotox. Environ. Safe. 60, 324-349.

TALAAT N.B. 2014: Effective microorganisms enhance the scavenging capacity of the ascorbate-glutathione cycle in common bean (Phaseolus vulgaris L.) plants grown in salty soils. Plant Physiology and Biochemistry 80, 136-143.

TALAAT N.B. 2015: Effective microorganisms modify protein and polyamine pools in common bean (Phaseolus vulgaris L.) plants grown under saline conditions. Scientia Horticulturae 190, 1-10.

STĘIEŃ W., GÓRSKA E.B., PIETKIEWICZ S., KALAJI M.H. 2014: Long-term mineral fertilization impact on chemical and microbiological properties of soil and Miscanthus $\times$ giganteus yield. Plant Soil Environ. 60 (3), 117-122.

VALARINI P.J., CRUZ DIAZ ALVAREZ M., GASCÓ J.M., GUERRERO F., TOKESHI H. 2002: Integrated evaluation of soil quality after the incorporation of organic matter and microorganisms. Brazilian Journal of Microbiology 33 (1).

YAMADA K., XU H.L. 2001. Properties and Applications of an Organic Fertilizer Inoculated with Effective Microorganisms. Journal of Crop Production 3 (1), 255-268 .

Streszczenie: Wpływ mikroorganizmów efektywnych na aktywność fotosyntetyczna roślin Arabidopsis $w$ warunkach stresu zasolenia. Zasolenie jest jednym z głównych abiotycznych stresorów, który wpływa na procesy fizjologiczne (np. fotosyntezy), ograniczając tym samym rozwój roślin. Celem niniejszej pracy była ocena wpływu zasolenia na wzrost i aktywność fotosyntetyczną roślin Arabidopsis oraz określenie możliwości wykorzystania mikroorganizmów efektywnych (EMs - efektywne mikroorganizmy) w podnoszeniu tolerancji tych roślin na stres zasolenia. Na podstawie otrzymanych wyników pomiarów fluorescencji chlorofilu $a$ stwierdzono, że zasolenie istotnie wpływa na efektywność fotosyntetyczną roślin. Zastosowanie EMs z kolei zwiększyło odporność roślin na ten stres, przy czym najlepsze wyniki otrzymano przy stężeniu EMs wynoszącym $10 \mathrm{ml} / 1$. Doświadczenie wskazuje, że wydajność kwantowa fotosystemu II jest wiarygodnym wskaźnikiem tolerancji roślin na stres zasolenia u roślin Arabidopsis, a mikroorganizmy efektywne mogą ograniczać skutki stresu solnego. 
MS received April 2016

\author{
Authors' addresses: \\ Hazem M. Kalaji, Magdalena D. Cetner, \\ Izabela A. Samborska, Stefan Pietkiewicz \\ Katedra Fizjologii Roślin \\ Wydział Rolnictwa i Biologii SGGW \\ ul. Nowoursynowska 159 \\ 02-776 Warszawa, Poland \\ Izabela Łukasik \\ ul. Racławicka 106, 02-634 Warszawa, Poland \\ Abdallah Oukarroum \\ Department of Chemistry and Biochemistry \\ University of Quebec in Montreal \\ C.P. 8888 , Succ. Centre-Ville, 8 Montreal \\ Quebec, H3C 3P8, Canada
}

Szymon Rusinowki

Instytut Ekologii Terenów Przemysłowych

ul. Kossutha 6, 40-844 Katowice, Poland

Michał Świątek

Instytut Technologii Mikrobiologicznych

al. Solidarności 9, 62-700 Turek, Poland

Piotr Dąbrowski

Katedra Kształtowania Środowiska

Wydział Budownictwa i Inżynierii Środowiska SGGW

ul. Nowoursynowska 166, 02-787

Warszawa, Poland

e-mail: piotr_dabrowski@sggw.pl 